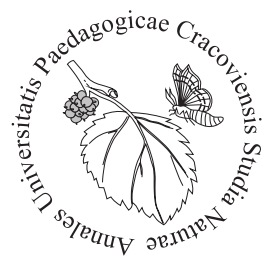

Sylwia Śliwińska-Wilczewska ${ }^{1 *}$, Agata Cieszyńska², Adam Latała ${ }^{1}$

${ }^{1}$ Institute of Oceanography, University of Gdańsk, Gdynia, Poland, ”ocessl@edu.pl ${ }^{2}$ Institute of Oceanology of the Polish Academy of Science, Department of Marine Physics, Marine Biophysics Laboratory, Sopot, Poland

\title{
The impact of temperature and photosynthetically active radiation on the growth and pigments concentration in Baltic picocyanobacterium Synechococcus sp.
}

Introduction

Chrococcoid cyanobacteria strain of the genus Synechococcus appears in marine, brackish, and freshwater ecosystems. Picoplanktonic organisms show a lot of adaptations, which enable them to spread in aquatic environments and to dominate and occupy the niches inaccessible for other photoautotrophs. Owing to the fact that picocyanobacteria exhibit the small size of cells and possess an advantageous surface area to volume ratio, they can assimilate trace amounts of nutrients. Therefore, in oligotrophic regions of seas and oceans, picoplankton can compete successfully with larger algae and determine the primary production of the whole water ecosystem (Six et al., 2007; Richardson, Jackson, 2007). Moreover, thanks to their small size and despite the absence of the gas vesicles, picocyanobacteria can float effectively in the ocean water.

The distribution and growth intensity of picocyanobacteria are determined by their optimal ecological requirements, such as light and temperature. These factors influence metabolic processes, photosynthetic pigments, photosynthetic activity, and consequently, the rate of cell division and growth. Cyanobacterial strains show outstanding acclimation capability, which enable them to survive in environments with a great variability in conditions. Some cyanobacteria are tolerant to high temperatures up to $70^{\circ} \mathrm{C}$ and can survive at low intensities of about $5 \mu \mathrm{mol} \mathrm{m}^{-2} \mathrm{~s}^{-1}$ (Stal et al., 2003).

Picocyanobacteria are a major component of oceanic ecosystems. Moreover, picocyanobacteria are important contributors to primary production in the ocean, particularly in warm nutrient-poor waters (Stockner, 1988). This suggests that the contribution of picocyanobacteria in temperate seas should be most important in the summer, when the water temperature is the highest and the seasonal thermocline limits the 
supply of nutrients to the upper layer (Agawin et al., 1998). Unfortunately, coherent investigations of physiological adaptations of picocyanobacterium Synechococcus sp. in aforementioned basins are scarce. Therefore, the objective of this work was to characterise the ecophysiological features of three different Baltic picocyanobacterial strains of the genus Synechococcus. The study was focused on estimating the effect of PAR and temperature on the wide range of changes in cell concentration and photosynthetic pigment content (Chl $a$ and Car). The autecological studies of the cyanobacterial species and the recognition of their reactions to the main environmental factor, such as light intensity and temperature, could be of great importance to recognise the phenomenon of picocyanobacterial blooms in aquatic ecosystems and an important step in the way to improved understanding of bio-geo-physical couplings in the water mediums.

\section{Material and methods}

The experiments were conducted on three different picocyanobacterial strains from the genus Synechococcus: red BA-120, green BA-124 and brown BA-132. Depending on pigment content, strains from the genus Synechococcus are classified as red strains with phycoerythrin, green strains rich in phycocyanin, and brown strains with phycourobilin and phycoerythrin (Mazur-Marzec et al., 2013; Jodłowska, Śliwińska, 2014). The strains were isolated from the coastal zone of the Gulf of Gdańsk (southern Baltic Sea) in late spring of 2002 and are maintained as unialgal cultures in the Culture Collection of Baltic Algae at the Institute of Oceanography, University of Gdańsk, Poland (Latała et al., 2006).

Tests on the 'batch cultures' were carried out in $25 \mathrm{ml}$ glass Erlenmeyer flasks containing sterilised f2 medium (Guillard, 1975). The media were prepared from artificial sea water with a salinity of about 8 . The strains were incubated under a $16: 8 \mathrm{~h}$ light : dark cycle at four PAR intensities $\left(10,100,190\right.$, and $\left.280 \mu \mathrm{mol} \mathrm{m}^{-2} \mathrm{~s}^{-1}\right)$ and at four temperatures $\left(10,15,20\right.$, and $\left.25^{\circ} \mathrm{C}\right)$. As a lighting source fluorescent lamps, Sylvania cool-white $40 \mathrm{~W}$ and Sylvania $100 \mathrm{~W}$ halogen lamps for more intense light were used. The intensity of PAR was measured by a LiCor LI-189 quantum-meter with a scalar collector. The cultures were acclimated to every culture condition for 2 days, and then they served as inoculum for experimental cultures where the initial number was $10^{6}$ cells per $\mathrm{ml}$. The test cultures were grown in three replicates and were incubated for one week. After that time in the exponential growth phase, the concentration of cells and contents of pigments were measured.

The number of Synechococcus sp. cells was determined using BD Accurim ${ }^{\mathrm{im}}$ C6 flow cytometer (Becton Dickinson, New Jersey, USA). The amount of picocyanobacteria was counted at delivery rate of $14 \mu \mathrm{min}^{-1}$ and identified using the Standard Optical Filter $670 \mathrm{~nm}$ (FL3) and 675/25 nm (FL4) (Marie et al., 2005). 
Chlorophyll $a$ and carotenoids were extracted with cold 90\% acetone in the dark for 4 hours at $-60^{\circ} \mathrm{C}$. To remove cell debris and filter particles, the pigment extract was centrifuged at $13000 \mathrm{rpm}$ for 2 minutes (Sigma 2-16P, Osterode am Harz, Germany). The extinction was determined at 750, 665, and $480 \mathrm{~nm}$ with a UV-VIS spectrophotometer - DU 530 Beckman using $1 \mathrm{~cm}$ glass cuvette. The concentration of carotenoids was calculated according to Strickland and Parsons (1972) with the formula: $\operatorname{Car}\left(\mu \mathrm{g} \mathrm{ml}^{-1}\right)=4\left(\mathrm{E}_{480}-\mathrm{E}_{750}\right) \mathrm{V}_{\mathrm{a}} / \mathrm{V}_{\mathrm{b}}$, while the concentration of chlorophyll $a$ was estimated with the formula: $\mathrm{Chl} a\left(\mu \mathrm{g} \mathrm{ml}^{-1}\right)=11.236\left(\mathrm{~A}_{665}-\mathrm{A}_{750}\right) \mathrm{V}_{\mathrm{a}} / \mathrm{V}_{\mathrm{b}}$, derived from the factor by Strickland and Parsons (1972), where $\mathrm{V}_{\mathrm{a}}$ - extract volume (ml) and $\mathrm{V}_{\mathrm{b}}$ - sample volume ( $\mathrm{ml})$.

The effects of PAR and temperature on the cell concentration and pigment content were examined by two-way analysis of variance method (ANOVA) at a significance level of $p<0.05$, and statistical calculations were performed using the STATISTICA ${ }^{\circ}$ 13.1 program.

\section{Results}

The concentration of cells of investigated Synechococcus strains were significantly $(p<0.05)$ affected by intensity and temperature (Fig. 1). The highest cell concentrations for strains BA-124 and BA-132 occurred in the highest light intensity $(280 \mu \mathrm{mol}$ $\left.\mathrm{m}^{-2} \mathrm{~s}^{-1}\right)$ and the highest temperature $\left(25^{\circ} \mathrm{C}\right)$, and they were about 15.8 -fold and 5.1fold, respectively higher than the concentrations in the lowest light intensity of 10 $\mu \mathrm{mol} \mathrm{m} \mathrm{m}^{-2} \mathrm{~s}^{-1}$ and $10^{\circ} \mathrm{C}$. For BA-120, it was found that the highest cell concentrations occurred in the scenario of $190 \mu \mathrm{mol} \mathrm{m}^{-2} \mathrm{~s}^{-1}$ and the $25^{\circ} \mathrm{C}$. Comparing the results derived within all experiments, the highest cell concentration $\left(36 \cdot 10^{6} \mathrm{cell} \mathrm{m} \mathrm{l}^{-1}\right)$ was noted in for BA-124 in the scenario mentioned above $\left(280 \mu \mathrm{mol} \mathrm{m}^{-2} \mathrm{~s}^{-1}, 25^{\circ} \mathrm{C}\right)$, and the lowest cell concentration was observed for BA-120 $\left(8 \cdot 10^{6} \mathrm{cell} \mathrm{ml}^{-1}\right)$ in $280 \mu \mathrm{mol} \mathrm{m}^{-2} \mathrm{~s}^{-1}, 10^{\circ} \mathrm{C}$ (Fig. 1). The other striking observation is that the abundance of BA-120 in the highest PAR is lower than the abundance in $190 \mu \mathrm{mol} \mathrm{m}^{-2} \mathrm{~s}^{-1}$. This tendency repeats for each temperature level (Fig. 1A).

In general, for the three strains of Synechococcus, the cell-specific pigmentation was negatively affected by high PAR (Fig. 2). The highest concentration of pigments were observed at the lowest light intensity $\left(10 \mu \mathrm{mol} \mathrm{m}^{-2} \mathrm{~s}^{-1}\right)$ and high temperature $\left(25^{\circ} \mathrm{C}\right)$, except for $\mathrm{Chl} a$ and Car in BA-124 cells, where the highest pigments content was noted at $10 \mu \mathrm{mol} \mathrm{m} \mathrm{s}^{-1}$ and $10^{\circ} \mathrm{C}$. The cell-specific composition of pigments content was different for different strains. The highest values of Chl $a$ and Car were observed in the red strain BA-120 (0.23 $\mathrm{pg}^{-1 l^{-1}}$ and $0.09 \mathrm{pg}$ cell $^{-1}$, respectively); whereas, in the green strain BA-124, the maximum value of this pigments was about $0.10 \mathrm{pg}^{-1 l^{-1}}$ and $0.07 \mathrm{pg}^{-1 l^{-1}}$, respectively. 


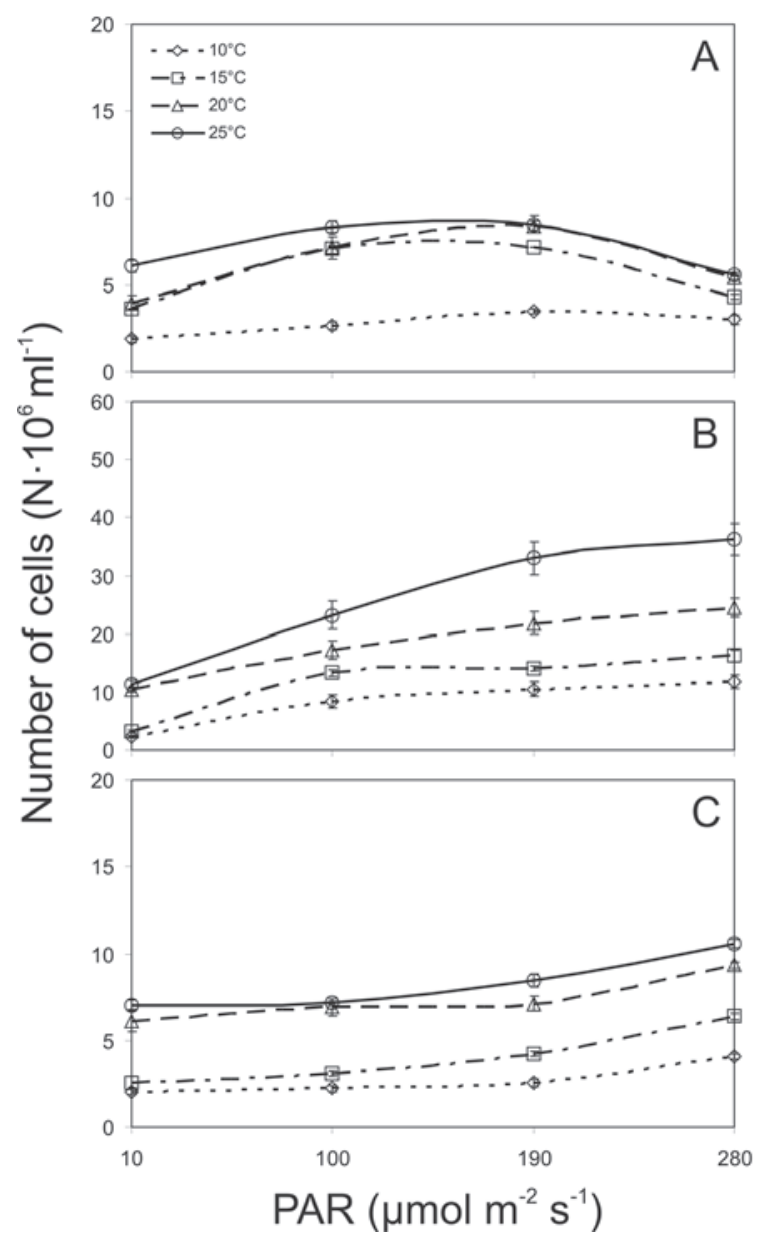

Fig. 1. Cell number of three strains of Synechococcus: BA-120 (A), BA-124 (B) and BA-132 (C) on day 7 of culturing at four PAR levels and at four temperatures. Values are means $( \pm S D) ; n=3$ of independent replicates. The scales in the sub-figures were prepared differently for different strains. This was done intentionally in order to facilitate reading the values in sub-figs $\mathrm{A}$ and $\mathrm{C}$

\section{Discussion}

According to the present results, PAR and temperature are important factors controlling the growth of picocyanobacteria. The significance of light and temperature was also emphasised by Jasser and Arvola (2003), who pointed to the impact of these factors on the abundance and also the distribution of picocyanobacteria in the water medium. Moreover, following some already published research, it can be claimed that temperature and PAR may determine the abundance of the marine Synechococcus community (Jasser, Arvola, 2003; Jasser, 2006; Flombaum et al., 2013; Jodłowska, Śliwińska, 2014). 


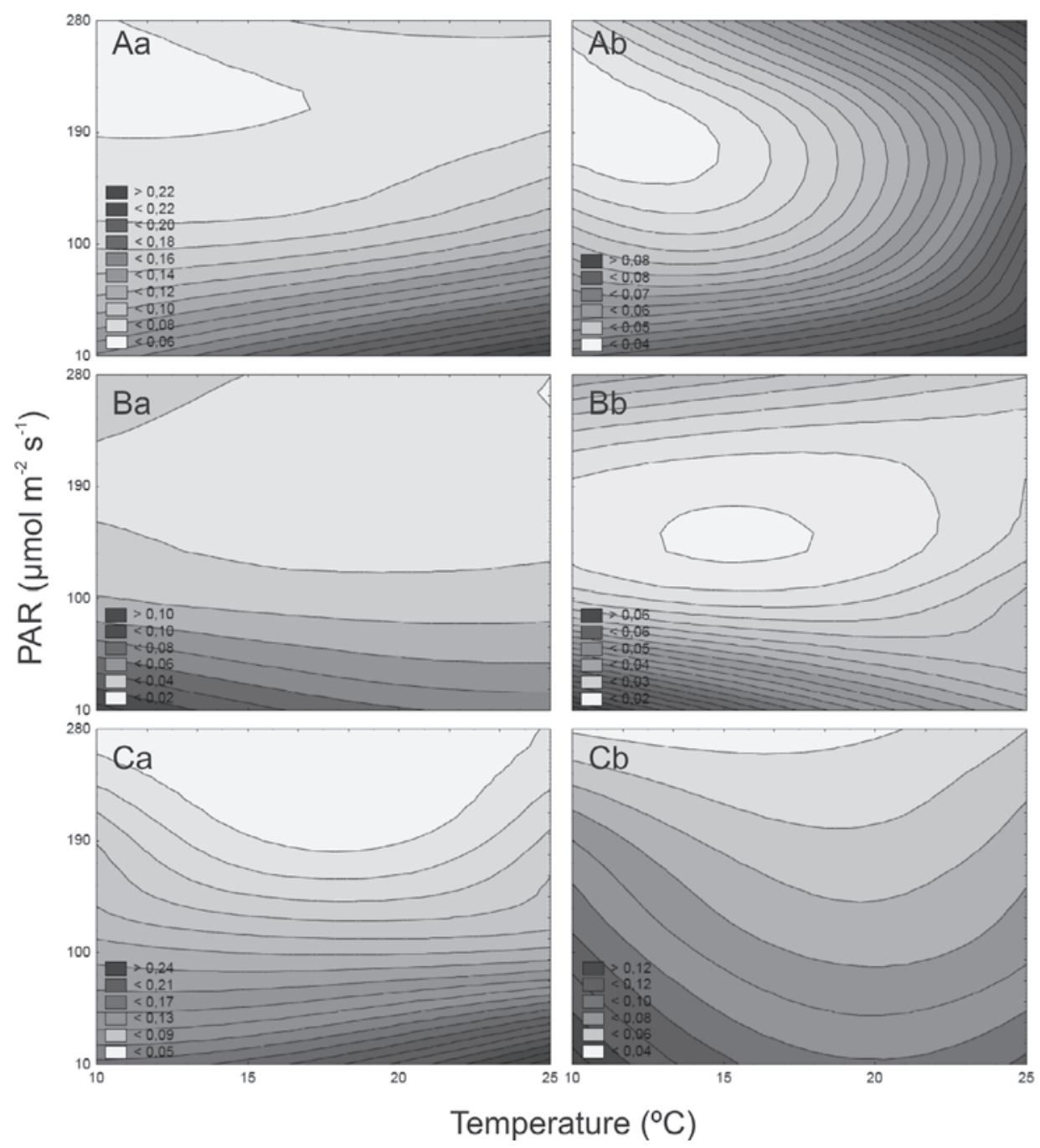

Fig. 2. The photosynthetic pigment content (pg cell $\left.{ }^{-1}\right)$ : a - chlorophyll $a, \mathrm{~b}$ - carotenoids for three stains of Synechococcus: BA-120 (A), BA-124 (B) and BA-132 (C) on day 7 of culturing at four PAR levels and at four temperatures. Values are means $( \pm S D) ; n=3$ of independent replicates

In this study, it was found that elevated PAR and temperature have generally a positive effect on cell concentration for Synechococcus sp. However, the adaptation to very low-light and low-temperature conditions are also known for picoplanktonic organisms. For instance, Ibelings (1996) noted that picocyanobacteria can benefit from low light intensity reaching high growth rates. Moreover, this statement is consistent with the observations of picocyanobacterial high abundance at (or near) the end of the euphotic zone in coastal and offshore marine waters (Callieri et al., 2005; Callieri, 
2010). Additionally, under culture conditions, some major picoplanktons demonstrated the ability to survive and resume growth after periods of total darkness. Such a pronounced capacity for survival in the dark would enable these picoplanktonic organisms to survive the seasonal rhythm of winter darkness and sinking into the aphotic zone (Antia, 1976). On the other hand, Kana and Glibert (1987a,b) showed that Synechococcus WH7803 could also grow at an intensity as high as $2000 \mu \mathrm{mol} \mathrm{m}{ }^{-2}$ $\mathrm{s}^{-1}$, but only if the cultivation of the strain was preceded by the acclimation in several intermediate intensities. Despite showing similar general growth responses to changeable environmental conditions, each strain also presents its specificity. For instance, a kind of growth saturation was measured for BA-120 between 190 and $280 \mu \mathrm{mol} \mathrm{m} \mathrm{m}^{-2} \mathrm{~s}^{-1}$ at each temperature level, where the abundance decreased along with PAR increase (Fig. 1A). Moreover, the abundance functions dependent on PAR and temperature are different for different strains. For example, for both BA-124 and BA-132 PAR and temperature have a positive impact on the abundance in the whole domain but the plot lines differ (Fig. 1B-C).

Surface and near-surface populations experience extremely variable light and temperature conditions (Millie et al., 1990), and intensity is an important factor that affects the composition of photosynthetic pigments (Prézelin, 1981). The results obtained for the two strains of Synechococcus BA-120 and BA-132 indicated that high intensity and low temperature had a generally negative effect on Chl a cell concentration. For BA-124, the maximum value of $\mathrm{Chl} a$ content was noted at the lowest light and temperature. The green strain BA-124 is rich in PC; whereas, the other two strains, red BA-120 and brown BA-132, have $\mathrm{PE}$ as the dominating photosynthetic pigment. Picocyanobacteria with a high concentration of PC are chromatically better adapted to harvest longer wavelengths of PAR than those with PE as a dominating pigment. Therefore, such picocyanobacteria (with PC) usually dominate in surface euphotic waters. On the other hand, the strains rich in PE usually occur deeper (Callieri, 2010). Moreover, picocyanobacteria, thanks to their high concentration of photosynthetic pigments, may occur in low light intensity waters (Stal et al., 2003). The above is consistent with derived results, which showed that BA-120 and BA-132 are characterised by higher a pigment composition than BA-124. BA-120 and BA-132 are these strains that are more adapted to live in deeper parts of the water column than BA-124. Note that changes in the pigment content and in the ratio of different pigments results in the optimisation of photosynthetic efficiency (Defew et al., 2004).

In the two strains of Synechococcus (BA-120 and BA-132), the highest Car content were observed at the lowest PAR and the highest temperature, whilst the highest Car content in BA-124 was measured at the lowest PAR and temperature. Carotenoids have a dual role in the cell, which is to maintain a high capacity for photosynthetic light absorption and to provide protection against photooxidation. This feature ad- 
ditionally explains why Synechococcus sp. is able to grow successfully both in the surface layer and in deeper waters (Stal, Walsby, 2000; Stal et al., 2003; Jodłowska, Śliwińska, 2014).

The experiments on Synechococcus strains demonstrated their tolerance to elevated light levels and temperatures. These strains were able to change the composition of photosynthetic pigments to use light quanta better and to protect themselves from unfavourable environmental factors. The ability of Synechococcus to sustain their growth in low light and temperature conditions and their lack (green and brown strain) or low photoinhibition (red strain) in exposure to high light intensities and high temperatures could give picocyanobacteria an advantage in changeable aquatic ecosystems.

This study indicates the need to conduct further research on Synechococcus sp. as a whole and separately for each strain of this genus. Only dedicated studies will bring detailed information about these microorganisms living not only in the Baltic Sea.

\section{Acknowledgements}

The authors would like to thank the anonymous reviewers for their valuable comments and suggestions to improve the quality of the paper. This study was supported by BMN grants, Poland, no. 538-G245-B568-17.

\section{References}

Agawin, N.S., Duarte, C.M., Agusti, S. (1998). Growth and abundance of Synechococcus sp. in a Mediterranean Bay: seasonality and relationship with temperature. Marine Ecology Progress Series, 170, $45-53$.

Antia, N.J. (1976). Effects of temperature on the darkness survival of marine microplanktonic algae. Microbial Ecology, 3(1), 41-54.

Callieri, C., Moro, S., Caravati, E., Crosbie, N.D., Weisse, T. (2005). Stain-specific photosynthetic response of freshwater picocyanobacteria. Verhandlungen des Internationalen Verein Limnologie, 29, 777-782.

Callieri, C. (2010). Single cells and microcolonies of freshwater picocyanobacteria: a common ecology. Journal of Limnology, 69(2), 257-277. DOI: 10.3274/JL10-69-2-08

Defew, E.C., Perkins, R.G., Paterson, D.M. (2004). The influence of light and temperature interactions on a natural estuarine microphytobenthic assemblage. Biofilms, 1, 21-30. DOI: 10.1017/ S1479050503001054

Flombaum, P., Gallegos, J.L., Gordillo, R.A., Rincón, J., Zabala, L.L., Jiao, N., Vera, C.S. (2013). Present and future global distributions of the marine Cyanobacteria Prochlorococcus and Synechococcus. Proceedings of the National Academy of Sciences, 110(24), 9824-9829. DOI: 10.1073/pnas.1307701110

Guillard, R.R.L. (1975). Culture of phytoplankton for feeding marine invertebrates. In: W.L. Smith, M.H. Chanley (eds.), Culture of Marine Invertebrate Animals. Plenum Press, New York, USA, 26-60. DOI: 10.1007/978-1-4615-8714-9

Ibelings, B.W. (1996). Changes in photosynthesis in response to combined irradiance and temperature stress in cyanobacterial surface waterblooms. Journal of Phycology, 32, 549-557. DOI: 10.1111/j.00223646.1996.00549.x

Jasser, I. (2006). The relationship between autotrophic picoplankton (APP) - the smallest autotrophic component of food web and the trophic status and depth of lakes. Ecohydrology and Hydrobiology, 6(1-4), 69-77. DOI: 10.1016/S1642-3593(06)70128-8 
Jasser, I., Arvola, L. (2003). Potential effects of abiotic factors on the abundance of autotrophic picoplankton in four boreal lakes. Journal of Plankton Research, 25(8), 873-883. DOI: 10.1093/plankt/25.8.873

Jodłowska, S., Śliwińska, S. (2014). Effects of light intensity and temperature on the photosynthetic irradiance response curves and chlorophyll fluorescence in three picocyanobacterial strains of Synechococcus. Photosynthetica, 52(2), 223-232. DOI: 10.1007/s11099-014-0024-y

Kana, T.M., Glibert, P.M. (1987a). Effect of irradiances up to $2000 \mu \mathrm{mol} \mathrm{E} \cdot \mathrm{m}^{-2} \cdot \mathrm{s}^{-1}$ on marine Synechococcus WH7803-I. Growth, pigmentation, and cell composition. Deep-sea research, 34(4), 479-495. DOI: 10.1016/0198-0149(87)90001-X

Kana, T.M., Glibert, P.M. (1987b). Effect of irradiances up to $2000 \mu \mathrm{mol} \mathrm{E} \cdot \mathrm{m}^{-2} \cdot \mathrm{s}^{-1}$ on marine Synechococcus WH7803-II. Photosynthetic responses and mechanisms. Deep-sea research, 34(4), 497-516. DOI: 10.1016/0198-0149(87)90002-1

Latała, A., Jodłowska, S., Pniewski, F. (2006). Culture Collection of Baltic Algae (CCBA) and characteristic of some strains by factorial experiment approach. Algological Studies, 122(1), 137-154. DOI: $10.1127 / 1864-1318 / 2006 / 0122-0137$

Marie, D., Simon, N., Vaulot, D. (2005). Phytoplankton cell counting by flow cytometry. Algal Culturing Techniques, 1, 253-267.

Mazur-Marzec, H., Sutryk, K., Kobos, J., Hebel, A., Hohlfeld, N., Błaszczyk, A., Toruńska, A., Kaczkowska, M.J., Łysiak-Pastuszak, E., Kraśniewski W., Jasser, I. (2013). Occurrence of cyanobacteria and cyanotoxin in the Southern Baltic Proper. Filamentous cyanobacteria versus single-celled picocyanobacteria. Hydrobiologia, 701, 235-252. DOI: 10.1007/s10750-012-1278-7

Millie, D.F., Ingram, D.A., Dionigi, C.P. (1990). Pigment and photosynthetic responses of Oscillatoria agardhii (Cyanophyta) to photon flux density and spectral quality. Journal of Phycology, 26, 660-666. DOI: 10.1111/j.0022-3646.1990.00660.x

Prézelin, B.B. (1981). Light reactions in photosynthesis. In: T. Platt, (Ed.), Physiological Bases of phytoplankton Ecology. Canadian Bulletin of Fisheries and Aquatic Sciences, no. 210, Ottawa.

Richardson, T.L., Jackson, G.A. (2007). Small phytoplankton and carbon export from the surface ocean. Science, 315(5813), 838-840. DOI: 10.1126/science.1133471

Six, C., Finkel, Z.V., Irwin, A.J., Campbell, D.A. (2007). Light variability illuminates niche-partitioning among marine picocyanobacteria. PLoS One, 2(12), e1341. DOI: 10.1371/journal.pone.0001341

Stal, L.J., Walsby, A.E. (2000). Photosynthesis and nitrogen fixation in a cyanobacterial bloom in the Baltic Sea. European Journal of Phycology, 35, 97-108. DOI: 10.1080/09670260010001735681

Stal, L.J., Albertano, P., Bergman, B., Bröckel, K., Gallon, J.R., Hayes, P.K., Sivonen, K., Walsby, A.E. (2003). BASIC: Baltic Sea cyanobacteria. An investigation of the structure and dynamics of water blooms of cyanobacteria in the Baltic Sea - responses to a changing environment. Continental Shelf Research, 23, 1695-1714. DOI: 10.1016/j.csr.2003.06.001

Stockner, J.G. (1988). Phototrophic picoplankton: an overview from marine and freshwater ecosystems. Limnology and Oceanography, 33, 765-775. DOI: 10.4319/lo.1988.33.4part2.0765

Strickland, I.D.H., Parsons, T.R. (1972). A practical handbook of seawater analysis. Journal of the Fisheries Research Board of Canada, 167, 1-310.

Abstract

The experiments on three Baltic picocyanobacterial strains of Synechococcus (BA-120 - red strain, BA-124 - green strain and BA-132 - brown strain) were conducted at four scalar irradiances in Photosynthetically Active Radiation (PAR) and four temperature levels. The main aim of this work was to estimate the effect of environmental conditions (temperature and PAR) on cell concentration and photosynthetic pigments (Chlorophyll $a-\mathrm{Chl} a$ and Carotenoids - Car) contents. The ranges 
of PAR and temperatures were $10,100,190,280 \mu \mathrm{mol} \mathrm{m} \mathrm{m} \mathrm{s}^{-1}$ and $10,15,20,25^{\circ} \mathrm{C}$, respectively. The experiment was carried in a medium of salinity of 8 . The number of Synechococcus sp. cells was determined using a BD Accuri ${ }^{\mathrm{mw}} \mathrm{C} 6$ flow cytometer. The pigments contents were determined by a spectrophotometric method. In this work, it was found that elevated intensity and temperature have, on average, a positive effect on cell concentration for Synechococcus sp. The highest cells concentrations were noted at the highest PAR $\left(280 \mu \mathrm{mol} \mathrm{m}^{-2} \mathrm{~s}^{-1}\right)$ and the highest $\mathrm{T}\left(25^{\circ} \mathrm{C}\right)$ for green and brown strains (BA-124 and BA-132, respectively) and at $190 \mu \mathrm{mol} \mathrm{m}^{-2} \mathrm{~s}^{-1}$ and $25^{\circ} \mathrm{C}$ for red strain (BA-120). Comparing the strains at each PAR level and temperature, the highest cell concentration was noted in green strain $\left(36 \cdot 10^{6}\right.$ cell $\left.\mathrm{ml}^{-1}\right)$, while the lowest was observed in red strain $\left(8 \cdot 10^{6} \mathrm{cell} \mathrm{ml}^{-1}\right)$. In general, in the two strains of Synechococcus (BA-120 and BA-132), the highest Car and Chl $a$ contents were observed at the lowest light intensity and the highest temperature. On the other hand, Car and $\mathrm{Chl} a$ maximum content in BA-124 were noted at the lowest light and temperature. The experiments on Synechococcus strains demonstrated their high capacity to acclimate to a wide range of PAR and temperature levels. The three strains of Synechococcus showed adaptation capabilities, since they were able to change the composition of their photosynthetic pigments to use light quantity better and to protect the cells from the unfavourable effect of elevated light and temperature.

Key words: picocyanobacteria, growth, PAR, photosynthetic pigments, temperature

Received: [2017.07.14]

Accepted: [2017.09.22]

\section{Wpływ temperatury i natężenia światła na wzrost i zawartość barwników fotosyntetycznych u bałtyckiej pikoplanktonowej sinicy Synechococcus sp. \\ Streszczenie}

Badania przeprowadzono na trzech szczepach bałtyckiej pikoplanktonowej sinicy z rodzaju Synechococcus (BA-120 - szczep czerwony, BA-124 - szczep zielony oraz BA-132 - szczep brązowy), które hodowano $\mathrm{w}$ czterech różnych warunkach oświetlenia fotosyntetycznie aktywnego (PAR): 10, 100, 190, $280 \mu \mathrm{mol} \mathrm{m} \mathrm{m}^{-2} \mathrm{~s}^{-1}$ oraz w czterech temperaturach: 10, 15, 20 i $25^{\circ} \mathrm{C}$. Głównym celem pracy było określenie wpływu wybranych zakresów PAR i temperatury na wzrost komórek oraz zawartość barwników fotosyntetycznych u analizowanych szczepów sinicy. Eksperyment przeprowadzono w medium o stałym zasoleniu równym 8. Liczebność komórek określana była za pomocą cytometru przepływowego BD Accuri ${ }^{\mathrm{im}}$ C6. Pomiar oraz estymację zawartości barwników fotosyntetycznych określono metodą spektrofotometryczną. Na podstawie uzyskanych danych wykazano, że wysoka intensywność światła oraz wysoka temperatura mają na ogół pozytywny wpływ na liczebność komórek Synechococcus sp. Stwierdzono, że szczep zielony (BA-124) oraz szczep brązowy (BA-132) osiągnęły największą liczebność komórek w najwyższym oświetleniu $\left(280 \mu \mathrm{mol} \mathrm{m}^{-2} \mathrm{~s}^{-1}\right)$ i najwyższej temperaturze $\left(25^{\circ} \mathrm{C}\right)$. Szczep czerwony BA-120 wykazał najwyższy wzrost w $190 \mu \mathrm{mol} \mathrm{m}^{-2} \mathrm{~s}^{-1}$ i $25^{\circ} \mathrm{C}$. Ponadto zaobserwowano, że szczep zielony posiadał najwyższą liczebność komórek, która po tygodniu eksperymentu wyniosła $36 \cdot 10^{6} \mathrm{kom} . \mathrm{ml}^{-1}$, natomiast szczep czerwony był najmniej liczny $\left(8 \cdot 10^{6} \mathrm{kom} . \mathrm{ml}^{-1}\right)$. Ogólnie, szczepy BA-120 oraz BA-132 najwyższą zawartość chlorofilu $a$ oraz barwników karotenoidowych wykazały w najniższym oświetleniu i najwyższej temperaturze. Maksymalną zawartość tych barwników szczep BA-124 osiągnął w najniższej temperaturze oraz natężeniu światła. Na podstawie przeprowadzonych doświadczeń wykazano wysoką aklimatyzację szczepów Synechococcus sp. do szerokiego zakresu natężenia PAR oraz temperatury. Wszystkie badane szczepy pikoplanktonowej sinicy były zdolne do zmiany proporcji swoich barwników fotosyntetycznych. Tego rodzaju umiejętność pozwala im lepiej wykorzystywać dostępne promieniowanie $\mathrm{w}$ procesie fotosyntezy oraz daje ochronę w przypadku ekspozycji na niekorzystne warunki środowiskowe.

Słowa kluczowe: pikoplanktonowe sinice, wzrost, PAR, barwniki fotosyntetyczne, temperatura 


\section{Sylwia Śliwińska-Wilczewska}

She is interested in allelopathy of cyanobacteria and microalgae, in particular, of picocyanobacteria $S y$ nechococcus sp. Her study includes the influence of allelochemicals on the growth, chlorophyll fluorescence, and photosynthesis irradiance curves of different phytoplankton species. She is investigating what influences environmental factors have on produced allelopathic compounds on algae and cyanobacteria.

\section{Agata Cieszyńska}

She is focusing on improving the understanding of the influence of different environmental conditions on phytoplankton blooms in the Baltic Sea. She is working on available data-bases and numerical models. Presently, she is working on the determination of the impact of ambient environment on picocyanobacteria growth on the basis of previously arranged laboratory experiments. Additionally, she is using the laboratory results to develop a numerical algorithm for the Baltic picocyanobacteria life cycle.

\section{Adam Latała}

Wide experience in ecophysiology and ecotoxicology of marine benthic and planktonic algae. Influence of the main environmental factors such as salinity, temperature and light on the photosynthesis, photoacclimation, fluorescence, respiration and growth of algae from natural communities and cultured under laboratory conditions. Use of fluorescence techniques to determine algal and cyanobacterial ecophysiology and ecotoxicology. 